\title{
POSTWAR HEURISTIC STRATEGIES OF EXCLUSION AND INCLUSION IN MOSCOW ARCHITECTURE
}

\author{
Leila Tavi (a)
}

\begin{abstract}
(a) Roma Tre University. Via Ostiense, 159, 00154 Roma RM, Italy.
\end{abstract}
E-mail: leila.tavi[at]uniroma3.it

\begin{abstract}
Moscow is a city of a thousand faces, constantly changing over the centuries and its high-rise buildings has been forming the shape of the city for centuries. From the «Third Rome», without stratified urbanization, unlike the Rome it would have liked to emulate at the end of the XIV century, Moscow went through a long period in history in which the innovations and changes made to its urban landscape overlapped the existing structure, erasing the architectural features and, thus, the historical memory. This article focuses on the transformation of Moscow from a Soviet capital to a capitalist mega-city, corroborating the thesis that the «immortalization of memory», through the monumental architecture of the Stalinist era, gave a sense of stability and was meant to be remembered by posterity. After the archetypal Soviet city, which embodied the Soviet Union's radiant future in the Thirties and Forties of the Twentieth Century, the city was characterized by a new urban appearance, made up of monumental buildings, privilege of apparatchiki (аппара́тчики), who lived in stalinki (сталинки), examples of socialist classicism, characterized by an original layout. Influenced by this Soviet legacy and its nostalgic impulses, Moscow's contemporary urban governance framework for planning reveals a strong nostalgia for the splendours of the past. The post-Soviet Muscovite experience resembles however more like a hybrid city than a palimpsestic one.
\end{abstract}

\section{Keywords}

Moscow; Post-socialist city; high-rise buildings; urban form; iconic buildings; urban redevelopment; urban planning; skyscrapers; urban design; monumentality

This work is licensed under a Creative Commons «Attribution» 4.0 International License. 


\title{
ПОСЛЕВОЕННЫЕ ЭВРИСТИЧЕСКИЕ СТРАТЕГИИ ИСКЛЮЧЕНИЯ И ВКЛЮЧЕНИЯ В МОСКОВСКУЮ АРХИТЕКТУРУ
}

\author{
Тави Лэйла (а) \\ (a) Университет Roma Tre. Via Ostiense, 159, 00154 Roma RM, Италия. \\ E-mail: leila.tavi[at]uniroma3.it
}

\section{Аннотация}

Москва - город с тысячами граней, постоянно меняющийся на протяжении веков, и ее многоэтажные здания формировали облик города на протяжении веков. От "Третьего Рима", без стратифицированной урбанизации, в отличие от Рима, которому она хотела бы подражать в конце XIV века, Москва прошла через длительный исторический период, когда нововведения и изменения, внесенные в ее городской пейзаж, перекрыли существующую структуру, стирая архитектурные особенности и, таким образом, историческую память. Данная статья посвящена трансформации Москвы из советской столицы в капиталистический мегаполис, подтверждая тезис о том, что "увековечение памяти" через монументальную архитектуру сталинской эпохи давало ощущение стабильности и предназначалось для того, чтобы о нем помнили потомки. После архетипичного советского города, олицетворявшего светлое будущее Советского Союза в 30-е и 40-е годы XX века, город характеризовался новым урбанистическим обликом, состоявшим из монументальных зданий, привилегией аппаратчиков, живших в сталинках, считавшихся образцами советского классицизма. Под влиянием этого советского наследия и его ностальгических импульсов современные градостроительные рамки Москвы обнаруживают сильную ностальгию по великолепию прошлого. Однако постсоветский опыт Москвы больше похож на гибридный город, чем на палимпсестический.

\section{Ключевые слова}

Москва; постсоциалистический город; высотные здания; городская форма; культовые здания; городская перепланировка; градостроительство; небоскребы; городской дизайн; монументальность

Это произведение доступно по лицензии Creative Commons «Attribution» («Атрибуция») 4.0 Всемирная. 
Moscow is a factory for making plans, the Promised Land of technicians (without a Klondike). The country is being equipped!

Le Corbusier, Precisions on the Present State of Architecture and City Planning (1930)

From the Tower of Babel onward, the fantasies of builders have been vertical rather than horizontal

Ada Louise Huxtable, The tall building artistically reconsidered: the search for a skyscraper style (1984)

\section{INTRODUCTION}

The structure and the identity of a city can be represented as a theoretic model. Therefore, the city can be analysed as a socio-cultural entity and as a major format of human residence. The past is a significant element for a conceptualization of the city as a space that is built and developed both in physical reality and in our minds. In this sense, the past of a city is not only part of history, but of a narrative that helps to better understand its society. Marxist geographer David Harvey (2003) and postmodern urban planner Edward Soja (2003), following the thinking of Henri Lefebvre (1996), have shown that urban space is not only a physical space, but the cultural imprint of a society. According to their theories, through a careful reading of these narratives of the city, it is possible to acquire a greater understanding of society's transformations.

Spatiality is the arena wherein social processes and interactions take place. For Roland Barthes (1986) the city is a «discourse», whose essence is the expansion of urban functions. His urban semiotic system is divided into rational material space semiotic system and perceptual emotion space semiotic system. The latter is composed of the figurative signifier and metaphysical meanings. In Roland Barthes' Urban Semiology (1988) there is a double meaning that has both philosophical and architectural significance. For Georg Simmel, «space in general is only an activity of the mind» and «the emphasis on the spatial meanings of things and processes is not unjustified» (1997, p. 138).

For Yuri Lotman the concept of the city should be associated with that of «semiosphere» (as cited in Lotman, 2002), which anticipated the "spatial turn» in cultural studies. Lotman's semiosphere is a metaphor, which offers a spatial model for the interpretation of culture. Lotman also draw a 
distinction between the «concentric city» of Moscow and the «eccentric city» of St. Petersburg. Fundamental to Moscow's urban identity is also Vladimir Paperny's theory of «Culture Two» (Paperny, 2006), in reference to Stalinist architecture.

Caroline Humphrey (2002) argues that Moscow presents not only a «psychological-ideological landscape», but also that this landscape «has specific post-Soviet contours». The image of Russia is therefore a polylogical country that combines core and periphery, centre and marginality, horizontality and verticality. It is a European «periphery» that has a beating heart, Moscow, which, in the perspective of a Russian pivot to Asia, is a candidate to be an alternative financial centre to London. The Russian capital has a special resonance as a synecdoche of the nation, surrounded by borderlands, whose survival depends on natural resources and whose liminal charge depends upon their core. This centre-periphery dichotomy produces a continuous feeling of failure and a need of repair. On the one hand, Moscow offers a vision of Russian society, while on the other hand, the city acquires «global» attractions: nostalgia for the glorious past, a period of rapid urban restructuring, a gated community, a suburb in contrast to the «Москва-Сити» ${ }^{1}$, the place of international finance. All the abovementioned factors should be analysed through local culture and history.

Moscow is an emerging world city, which is still obsessed with its Soviet legacy. With its vision of the «new capital» of the year 2020, the master plan of 2004 draws inspiration from the General Plan of 1935, with the magnificence of Stalin-era monumentalism, its vertical development, and its original skyscrapers. Moscow today bears the future of Russia. It is a city full of the phantasmagoria of past eras, but which can be shaped for new geographies and new types of urban environments. Above all, it is worth to mention the geography of Russian government organization, combined with the financial and trade sphere of the Moscow International Business Center ${ }^{2}$.

Moscow is a symbol of a power still conceived as power over the space, based on a new patriotism, limiting the influence of the new urban middle class and concentrating the wealth in few hands, in a sort of hierarchical patronage, whose symbols are the skyscrapers. These new Putinskie Vysotki ${ }^{3}$ are the result of new economic settings for architectural planning, in a city that fluctuates between traditionalism and modernism.

\footnotetext{
${ }^{1}$ Moskva-City.

2 Московский международный деловой центр.

${ }^{3}$ Путинские высотки.
} 


\section{THE SOVIET LEGACY}

Unlike other forms of Classical Revival, the neoclassicism expressed by the socialist realism developed its own peculiar way of critically reinterpreting the concept of classicism, which we cannot consider as an imitative style, but as an eclectic iconographic system, conceived according to the Leninist principle that everything good in a culture of the past was created regardless of the policies of the respective ruling class (Paperny, 2002).

Moscow had to represent a model that was no longer the utopian city desired by the Russian architects of the 1920s, who understood cities as small, anonymous, and circumscribed realities, measured on a human scale and spread throughout the territory in a homogeneous way. With its skyscrapers, Moscow became the reference point and model for other capitals of the Soviet bloc, as well as the antagonist par excellence of New York, the Western symbol of the melting pot and utilitarianism (Kruzhkov, 2014). It was therefore necessary to replace the utopian projects for those skyscrapers, that until then Russian architects had only built on paper $^{1}$, with concrete projects, eclectic and solid at the same time, that could convey an educational message to the masses, inspiring in the citizens at the same time trust and fear in the regime (Behrends, 2015).

If we compare the New York skyscrapers in those years, they truly represented an example of capitalism without ideology, based on the optimisation of logistics costs and the workforce employed there. Instead, the Moscow Seven Sisters' projects hinged on an archaic structure, with elements of Roman imperial and medieval architecture, to create an effect of triumph and power, combined with the hierarchy of the Russian Orthodox cathedrals and «the principles of the formation of vertical dominants and stable horizontal composition» (Golovina \& Oblasov, 2018, p. 13).

Influenced by politics and ideology, Russian architects were skilled at exploiting the idea of verticality as an elevation axis, taking some ideas from the Constructivism. The «common houses» that Le Corbusier saw in Moscow between 1928 and 1929 inspired his idea of ville radieuse of 1931, whereas the Muscovite skyscrapers were conceived as redundant granitic high-rise buildings, showing a reckless opulence, compared to the essential and luminous skyscrapers theorized by Le Corbusier.

The Russian ville radieuse was declined then in светлое будущеее, in a national form and in solid granite, no longer in a universal message and

\footnotetext{
${ }^{1}$ As in the case of The City of Skyscrapers, an architectural fantasy of Jakov Chernikhov (Яков Георгиевич Чернихов), a constructivist architect and graphic designer.
} 
with innovative materials. Those high-rise buildings were shaped with experimental design techniques, together with Neoclassicism and NeoRenaissance elements (Van Baak, 2009). The result was «national in form» (Cooke, 1997, p. 137) within the peculiar Russian context, with a centripetal perspective, and no longer with centrifugal dynamism, giving to the buildings a special Soviet pathos. Since 1933 the Academy of Architecture of the Union of Soviet Socialist Republics supervised every project, implementing to the letter the directives of the $\mathrm{CPSU}^{1}$, which obliged architects to design buildings that were «socialist» in content, but «national» in form, to represent Moscow's peculiar melting pot, so different from the New York one. This particular image of Moscow helped, together with the Stalinist mass culture, the formation of a Russian national identity between 1931 and 1956 (Brandenberger, 2002).

Thanks to this historical fictio $^{2}$, Stalin intended to shape a Soviet multi-ethnic society, according to a cultural model, which was, in a provocative way, in continuity with the Tsarist tradition (Kappeler, 2008). The homo sovieticus, which acquired after the death of Stalin a negative meaning, represented in Stalin's era the synthesis between individual local traditions and myths. This ideological/cultural mixture represented furthermore a symbology known, understood, and shared by all ethnic groups in the Soviet Union and taken as a model from its satellite States (Harding, 2013).

In this perspective, Moscow had to be developed in height and depth. The suburban and underground dimension had been conceived for the masses, especially the metro. Moscow working-class journey to the workplace had to be as pleasant as possible; the stations were therefore, on the instructions of Lazar Kaganovich, embellished with statues in typically proletarian poses, twenty different qualities of marble, a sumptuous illumination. Metaphorically, the metro had to lead the Soviet proletariat towards a «bright future». An impressive slogan, but without the utopian goals of the revolutionary period (Lemon, 2000), which was replaced with the more general concept of «сталинская забота о человеке» ${ }^{3}$, very helpful in order to create a metropolitan image for Moscow architecture (Vasilyeva \& Kosenkova, 2015). In this sense, the masses became aware of the concept of public good, which manifested itself in all its beauty.

On the contrary, the verticality of the skyscrapers, according to a hierarchical-feudal legacy, was a prerogative of the nomenklatura ${ }^{4}$, which

\footnotetext{
${ }^{1}$ КПСС or CPSU in English - Communist Party of the Soviet Union (disambiguation).

${ }^{2}$ As it happened for nationalism in mid-nineteenth century Europe.

${ }^{3}$ Stalinskaya zabota o cheloveke, or Stalin's solicitude about man

${ }^{4}$ Номенклату́ра.
} 
in the last period of the Stalinist regime resembled what Simon Sebag Montefiore describes as a «political dining society» (2004, p. 537). With Stalin, also the skyscrapers became a political issue, or better a political vehicle.

Like ivory towers, some of the Moscow skyscrapers were used as residential buildings hiding inside a microcosm of their own, separated from the life of ordinary citizens. Far from prying eyes, individualism and unbridled luxury were granted, at least as long as one remained in Stalin's good graces. A category of privileged people, who drove luxurious autos, like the ZIS models, resembling the ruling class described by Milovan Đilas in his book The New Class (Djilas, 1957) ${ }^{1}$. Certainly, those powerful men did not travel by metro, walking through the crowded metro stations, like the thousands of workers.

For the devastated Russian society, with its victorious but difficult exit from the Second World War, the bright future represented an ideological slogan, as American consumerism used advertising.

With its vast urban space, Moscow was used as the образ badge of that slogan. The «Seven Sisters», built around the centre of the city between 1947 and 1951, became an expression of Soviet grandeur and the answer to Western capitalism. The Soviet skyscrapers were characterized by façade decorations, example of a reactionary aesthetic, which was a consequence of the continuing need for self-celebration of the totalitarian regime and its bureaucracy.

For the Soviet nation and its father Stalin, the radiant future meant above all victory, whose symbols were those extraordinarily «radiant» structures, which gradually emerged from the Moscow construction sites between 1947 and 1951. Gleaming and topped with gold, Moscow skyscrapers were recognizable by their church-like form and their traditional three-dimensional placing within the city (Cooke, 1997).

Instead of becoming a tangible evidence of the «Promised Land of technicians», declaimed by Le Corbusier (1991, p. 260) during his trip to Russia, the new monolithic giants of Moscow, were an expression of a dim magnificence based on a damnatio ad metalla ${ }^{2}$. Those skyscrapers were symbols of a hierarchical ideological empire and expression of the selfreferential narcissism of a single man, which to a Western observer of that time could appear a «more 50-foot Stalins on the roof» (Blake, 1947, 127).

\footnotetext{
${ }^{1}$ The original title of the book is Nova klasa: kritika savremenog komunizma.

2 To build the Muscovite skyscrapers were used mainly Gulag political prisoners and German prisoners of war, considered as slaves.
} 
Moscow urbanisation plan had an ambitious project, the Palace of the Soviets ${ }^{1}$, begun and never finished, because of the war (Cetin, 2011). It was to be built on the site of the Cathedral of Christ the Saviour ${ }^{2}$, at the time the highest Orthodox church in Russia, demolished in 1937 to make room for a building that could have been the ideal place to house a «practical facility for the hosting of International Communist Party plenums» (Hoisington, 2003, p. 45).

What Anatole Kopp refers to as «gigantisme symbolique» (1985b, p. 56), transformed the city of Moscow into a tangible symbol of Soviet power; a celebration of a Pantagruelian modus vivendi, which had to satisfy the aesthetic taste in architecture of the Russian political elite with its excesses.

That aesthetic taste was condemned during the XX Congress of the PCUS of 1956 by Khrushchev ${ }^{3}$ himself, who intimated to the president of the Soviet Academy of Architecture, Arkady Mordvinov ${ }^{4}$, not to waste any more money on «architectural over-indulgences» (Cooke, 1997, p. 137) with expensive decorations.

A new course was inaugurated at the end of the 1950s: the facades of the buildings had no ornaments, but square lines. Soviet architecture had to return to austere forms, without showing the futuristic impetus of the early Twentieth-century Constructivism.

Industrialization had an immediate effect on housing construction: in the Soviet Union the construction of dwellings tripled between 1950 and 1960, from 20 million $\mathrm{m}^{2}$ to 59 million $\mathrm{m}^{2}$ (Andrusz, 1984). The sophisticated buildings of the «сталинский ампир» ${ }^{5}$ were replaced by mass housing blocks, called полусталинки-полухрущёвки ${ }^{6}$, a sort of spare buildings still designed according to the rules of the Stalin's Empire style, «ободранные сталинки» ${ }^{7}$ from 1956 to 1960.

Later came another hybrid form of post-Soviet urbanity for the Russian working class: the хрущёвки ${ }^{8}$, followed by the брежневки ${ }^{9}$. From the beginning of the 1970s to the beginning of the 1990s, we can count four waves of industrial housing construction. On the ashes of a decayed socialist city rose again a new metropolis, symbol of a State that has been trying to regain a role of great power in the world.

\footnotetext{
${ }^{1}$ Дворец Советов (Dvorets Sovetov).

${ }^{2}$ Храм Христа Спасителя (Khram Khrista Spasitelya).

${ }^{3}$ Никита Сергеевич Хрущёв.

${ }^{4}$ Аркадий Григорьевич Мордвинов.

${ }^{5}$ Stalinskii Ampir, or Stalinist Empire style

${ }^{6}$ Polustalinki-poluhrushchyovki.

${ }^{7}$ Obodrannye stalinki.

${ }^{8}$ Khrushchyovki.

${ }^{9}$ Brezhnevki.
} 
As Gunko, Bogacheva, Medvedev \& Kashnitsky (2018) explain, in 1999 the Moscow government started the programme «Comprehensive reconstruction of the areas of five-storied apartment buildings built during the first period of industrial housing construction». That programme included the demolition of most of the khrushchyovki, that had to be replaced by recreational spaces, public utility buildings, and residential constructions. Only some khrushchyovki were renovated and rebuilt by private initiative, with private investment. Those remained khrushchyovki are colloquially called khrushchyoby ${ }^{\prime}$, a combination of the words khrushchyovki and trushcheby ${ }^{2}$, but without acquiring a meaning of ethnic segregation or socio-economic disparity (Demintseva, 2017; Vendina, 2004).

Urbanization growth under the Soviet regime was an expression of the modernization of the territory from the social, technological, and economical points of view, but it was also the expression of an ideological project, underlined by radical political turns in the architecture, a strict political control over the urban territory and over the production of the city and the allocation of dwellings (Inizan, \& de Lille, 2019).

\section{MOSCOW CONTEMPORARY VERTICAL URBANISM}

After the collapse of the Soviet Union in 1991, the idea of architecture borrowed from the Stalinist era is present in nuce in Moscow new megastructures. (Griffiths, 2014; Dmitrieva, 2006). With the 1992 Moscow Structure Plan, launched by Mayor Luzhkov ${ }^{3}$ during his first term in office, the concept of a block city, with a more differentiated housing supply was introduced. Moscow offered luxury buildings for the glittering residential districts, where the new businessmen lived, while the colourful districts on the outskirts of Moscow were intended for middle-income families, and the rest of the city, with its anonymous appearance, for the masses (Alden, Beigulenko, \& Crow, 1998).

This housing differentiation in Moscow's urban layout demonstrates the overcoming of societal equality in favour of the needs of the individual and his disposable income. The neoliberalism inaugurated by Luzhkov was the response to the housing needs of a middle class that was constantly growing in Moscow until the global financial crisis of 2008. In this framework, the differentiation of housing supply results in today Moscow

\footnotetext{
${ }^{1}$ Хрущобы.

2 Трущобы - slums in Russian.

3 Юрий Миха́йлович Лужко́в, (born September 21, 1936, Moscow, Russia, U.S.S.R.—died December 10, 2019, Munich, Germany).
} 
as socio-spatial segregation (Kuznetsov, 2015), also because Moscow has always attracted migrants from Central Asia and Russia's remote regions.

During the 2000s, the city's historical concentric structure has been developed upwards, demonstrating a renewed obsession with the verticality of Stalin's times. Luzhkov intended to turn Moscow into a global city. He supported the construction of ultra high-rise buildings, such as the skyscrapers of the Moscow International Business Centre ${ }^{1}$. His urban plan was favoured by the patronage of big business and the rise in oil and gas prices in the early 2000s, which attracted foreign capital to Moscow and «drove a construction boom that resulted in the proliferation of hypermodern skyscrapers across the city» (Büdenbender \& Zupan, 2017, p. 302).

What is interesting is that the imposing Moscow financial centre is composed of towers. This choice enhances the cultural sense of this architectural element, as confirmed by the etymology of the word «tower» ${ }^{2}$, which in Russian is башня ${ }^{3}$, derived from the Turkish baş, meaning «head».

«A tower as a head extends this meaning to the cultural body, creating a corporeal metaphor: the head as a political/social leader» (Zlydneva, 2008, p. 86). The word head can also be a metaphor for power, which can be declined in the case of Russia as masculine authoritarian power. Moscow towers/skyscrapers are therefore a symbol of the power of the State and serve as a trait d'union to the historical periods that have shaped Moscow urban landscape, especially during the Muscovite State. In the 16th and 17th centuries the natural conformation of Moscow, developed on several hills, was used as one of the arguments for describing Moscow as the hypothetical successor of the Roman Empire (Pliukhanova, 1995).

In spite of its early 1990s haphazard beginnings, Luzhkov's urban development model worked, because it contained characteristics that were well suited to existing socialist structures: elite-networks, technocracy, public ownership of buildings and land (Jensen, 2000). Mass privatization of housing entered into force in Russia on 4 July 1991, when the law «On privatization of housing fund in the Russian Federation» was adopted ${ }^{4}$ (Kosareva \& Struyk, 2010). Luzhkov preferred not to sell off Moscow's public buildings, but to use private capital for their restructuring and modernization. The result was that Moscow recovered much more quickly

\footnotetext{
${ }^{1}$ Московский международный деловой центр (Moskovskiy mezhdunarodniy delovoy tsentr) has been designed by Swanke Hayden Connell Architects.

${ }^{2}$ Some of the high-rise buildings in contemporary Moscow are named towers. The etymology of the word is: Old English torr, from Latin turris, meaning citadel or high structure.

${ }^{3}$ Bashnya.

${ }^{4}$ «Privatization was individual and voluntary and, if desired, residents could continue living in their apartments without privatizing them on terms of social hiring. At the present time, there are still around $10 \%$ of apartments in Moscow which are not privatized» (Gunko at al., 2018, p. 290).
} 
from the collapse of the Soviet Union than other Russian cities, also because Moscow became an attractive outlet for international investments.

Moscow under Luzhkov kept the Soviet practice of requiring a notice of the permanent living place ('propiska'), as the government wanted to limit uncontrolled migration and homelessness, although the process of registration is very bureaucratic (Astapova, 2013, p. 8).

Luzhkov behaved in relations with Muscovite citizens as хозяин ${ }^{1}$, trying to balance his actions between the interests of the State, those of the elite and the public good. In times of hyperinflation he used commune property as an alternative currency, with the tacit consent of the Muscovites, who agreed to maintain a Soviet-style management of their city in order to have guaranteed urban growth and economic stability. (Zupan \& Büdenbender, 2018). Using Soviet practices and structures and insisting on three fundamental pillars of Russian culture: orthodoxy, autocracy and national identity, Luzhkov laid the foundations for a benevolent authoritarian neoliberal model (Zeltsman, 2011). This urban patronage management is called «Luzhkov compromise», while the related post-modern vernacular architecture made of eclectic-classical buildings is called «Luzhkov style».

This is how Daria Paramonova ${ }^{2}$ describes the Luzhkov style:

Yury Mikhailovich's personal interpretation of context and history led to a bastardized classicism being acknowledged as the right style for the historic areas of Moscow. The audacity with which architects could use the obligatory historical elements - pillars, cornices, and the like - led to some extremely strange buildings. You can't even call them postmodern, because the theory of postmodernism is far more complex. The popularity of the contextual idea was also economically dictated. Investment, construction, profitability ... they became magic words to justify all kinds of cultural abomination (Clark \& Tsibizova, 2017).

The Soviet legacy is a key element in the urban development of the Luzhkov years. In almost two decade, the mayor with an iron fist used to

\footnotetext{
${ }^{1}$ Khozyain means leader of any social sphere, a home, village or enterprise, who is responsible for business but also takes care for his people.

${ }_{2}$ Dasha Paramonova is an architect, urban planner, and head of the Strelka Institute for Media, Architecture and Design (Институ́т ме́диа, архитекту́ры и диза́йна «Стре́лка» Institut Media, Architektury i Dizajna «Strélka»), author of book about architecture Luzhkov era (Paramonova, 2013).
} 
reshaped the city, supported by his wife Yelena Baturina ${ }^{1}$, who is the only woman among Russian billionaires with a fortune of $\$ 1.2 \mathrm{bn}$. «Taking the city as a canvas, Luzhkov has written into the cityscape narratives of the nation, its past and its future. Yet the result is incoherent and contradictory, creating a dizzying sense of cognitive dissonance» (Griffiths, 2014, p. 54)

The first building 100+m in Russia was completed in 1995 - the Gazprom Tower in Moscow (150m). Outside Moscow, the first building of 100+ was Uralsib Bank's office, Ufa, 1999. By the 21st century, there were $25100+$ buildings in Russia. Modern high-rise construction began after the 1998 crisis. The first new ones were three 115-m towers of residential complexes at Leninsky Prospect in Moscow. Triumph Palace residential complex (264m), 2005, Naberezhnaya Tower (268m), 2007, City of Capitals complex (302m), 2009, Mercury City Tower (339 m), 2013, OKO complex (about $354 \mathrm{~m})$. Now the highest in Russia and Europe is the Federation Tower $(364 \mathrm{~m})^{2}, 2017$, arch. nps+partner, Schweger Associated Architects. As a result, an area with ultra-high buildings appeared in Moscow, which is not found elsewhere in the world, except for the DubaiMarina area (Iconopisceva \& Proskurin, 2018, p. 5).

High-rise architectural concepts of Luzhkov's Moscow reproduce in a clashing way the «Stalin Gothic style», according to an ambitious planning vision, based on mythology, hierarchy and centripetal concentricity, as theorized by Paperny (Wolfe, 2013). With Putin's coming to power and his growing passion for the вертикали власти or vertical of power ${ }^{3}$, the tendency was to expand Russian cities no longer outwards, therefore horizontally, but upwards. At the beginning of the Second Millennium, the vertical design of Moscow has many examples, including the Patriarch ${ }^{4}$,

\footnotetext{
${ }^{1}$ Еле́на Никола́евна Бату́рина (born in Moscow, 8 March 1963).

2 The Federation Tower (Башня Федерации, Bashnya Federatsii) is a complex of two skyscrapers built on the 13th lot of the Moscow International Business Center (MIBC) in Moscow, Russia. The two skyscrapers are named Tower East or Vostok (Russian: Восток, East) and Tower West or Zapad (Russian: Запад; literally means "West").

${ }^{3}$ Political analysts borrowed this term from a film of 1967, Vertikal, a favourite of Putin, who knew all its songs by heart. Вертикаль is a Soviet sports drama film directed by Stanislav Govorukhin (Станислав Сергеевич Говорухин) and Boris Durov (Борис Валентинович Дуров). It was among the box office leaders of that year. In relation to Russian politics, this term describes a vertical chain of hierarchical authority.

${ }^{4}$ Тhe Дом Патриарх is a 12-story luxury apartment building on Malaya Bronnaya Street (Ма́лая Бро́нная у́лица), built in 2002 and designed by the Moscow architects Sergei Tkachenko (Сергей Борисович Ткаченко) and Oleg Dubrovsky (Олег Дубровский). The luxurious building overlooks Patriarch Ponds (Патриаршие пруды) and is decorated with mosaic marble floors, columns, and twelve sculpture made by Vladimir Kurochkin (Владимир Борисович Курочкин). Among the statues one can recognize Kurochkin himself as a sculptor, and Sergei Tkachenko with a drawing in his hands, and Oleg
} 
with a spire that resembles Tatlin's Tower ${ }^{1}$; the base of the building has a stepped body similar to a wedding cake in typical Stalinist style. Three other examples of pseudo-Stalinist style are the Triumph-Palace ${ }^{2}$ residential complex, built on Chapaevskii pereulok ${ }^{3}$ and the Edelweiss Tower ${ }^{4}$ on Davydovskii pereulok ${ }^{5}$. The latter two buildings have often been compared to the Seven Sisters of the Stalinist era (Honda, 2012). Another example of high-rise buildings built drawing inspiration from the skyscraper projects of the past are the City of Capitals ${ }^{6}$, which is a mix-used complex located in the Moscow International Business Center, for which was taken as a model Tatlin's pre-Revolutionary counter-reliefs, three-dimensional constructions made of wood and metal.

«Tatlin experimental work in the early $20^{\text {th }}$ century marked an attempt to redefine sculpture's relationship to build space» (Starodubtsev, Myers, \& Goetz. 2011, p. 13). The unconventional architecture of the tower theorized by Tatlin is distorted in contemporary Moscow, where widespread skyscrapers destroy the perception of the building as an exceptional architectural monument.

This is an interesting description of the new high-rise buildings of Luzhkov era made by Griffiths in his doctoral thesis discussed in 2014:

Not only do the Triumph Palace's 'wedding-cake' structure and soaring spire bear remarkable resemblance to Stalin's famous skyscrapers, but the Edelweiss Tower was the first building to be completed as part of another scheme with Stalinist overtones, the plan to construct the 'Novoe kol'tso Moskvy". The ring of skyscrapers was incorporated into the General Plan for 2020, first presented to the Moscow City Duma in 1999 and finalized in 2005, and the concept was supported by Luzhkov. More ambitious in scale than the 'first ring' of seven vysotki, the 'new ring' was intended to consist of sixty towering complexes by 2015. One of the skyscrapers pencilled in for Leninskii prospekt neatly captures the scale of the architectural ambition with its simple designation - 'Vertikal'. However, with

Dubrovsky with a house model, and the chief architect of Moscow Alexander Кuzmin (Алекса́ндр Ви́кторович Кузьми́н), who died on September 26, 2019.

${ }^{1}$ Ба́шня Та́тлина, a project for the Monument to the Third International (1919-20) by Vladimir Tatlin (Влади́мир Евгра́фович Та́тлин), which was never built.

2 Триумф-Пала́c, complete in 2006.

3 Чапа́евский переу́лок

4 Эдельвейс. Built between 2000 and 2003, the tower has 43 floors and is decorated with multiple turrets.

5 Давыдовский переулок.

${ }^{6}$ Город Столии (Gorod Stolits) was designed by the U.S. company NBBJ in 2002. This mixed-use complex was developed between 2005 and 2009, then completed in 2010 . The $300000 \mathrm{~m}^{2}$ project consists of two towers of 62 and 73 storeys, preceded by a conical dome.

7 Но́вое кольцо́ Москвы́. 
investors already reluctant by the mid-2000s to keep Vertikal' rising amidst soaring costs, the plan ultimately foundered in the ensuing uncertain economic times. The scheme was quietly scrapped in August 2011, by which point only six of the sixty skyscrapers had been completed or were nearing completion (pp. 68-69).

Besides the Edelweiss Tower there are five other buildings, which belong to the "New Ring of Moscow" project: the Kontinental ${ }^{\text {, }}$, the Well House $^{2}$, the Bastion, ${ }^{3}$, the Sokolinaja Gora ${ }^{4}$, and the Preo- $8^{5}$. Another residential building complex that belongs to the Luzhkov style that is worth mentioning is the Scarlet Sails ${ }^{6}$

At the end of the first decade of the new millennium, the financial crisis and the fall in oil prices have drastically reduced the ambitious plans to turn Moscow into a financial hub that could compete with London, where the rich Russian oligarchs have previously invested the proceeds of oil and gas production, buying some of the most expensive properties. Anyway, between 2000 and 2008 Moscow grew more than any other town in Eastern Europe, in terms of urban development and connectivity to the global network.

The construction of towers and skyscrapers was concentrated on the banks of the river, just outside the Sadovoe kol'tso ${ }^{7}$, where Bashnia ${ }^{8}$ was started to be built already in 1996. The building was completed in 2001 and was the first building of the urban complex called Moscow City ${ }^{9}$. Luzhkov

\footnotetext{
1 Жилой комплекс «Континенталь», the residential complex Continental situated on the Marshal Zhukov avenue (Проспект Маршала Жукова) was built between 2005 and 2011.

2 «Well House на Ленинском». Велл Хаус на Ленинском or Wellhouse at Leninsky Prospekt was built between 2002 and 2009.

3 Бастион is situated on Profsoyuznaya street (Профсоюзная улица) and was built between 2006 and 2012 by the team of Aleksey Bavykin (Алексей Бавыкин), Michail Marek (Михаил Максимович Марек), Andery Vlasenkov (Власенков Андрей), and Grigory Guryanov (Grigory Guryanov) for the companies Praycast (2006-2010) and Tashir (2010).

4 Соколиная Гора on Semyonovskaya square (Семёновская площадь) was built between 2005 and 2008.

5 The «PREO 8 business centre» (Бизнес-центр «ПРЕО 8») is a commercial property complex in the historic district of Moscow, on Preobrazhenskaya square (Преображе́нская пло́щадь). Тhe project is by $\mathrm{ABD}$ architects.

6 «Алые паруса» on Aviatsionnaya street (Авиационная улица) was built between 2000 and 2003. The name is inspired by the traditional celebration in Saint Petersburg which began in 1968, when several Leningrad schools united to celebrate the end of the school year in connection with the symbolism of the popular 1922 children's book Scarlet Sails by Alexander Grin (Александр Грин).

${ }^{7}$ Садо́вое кольйо́, meaning the Garden Ring.

${ }^{8}$ Башня 2000, also called Tower 2000.

9 «Москва-Сити» - деловой район на Пресненской набережной. The Moscow International Business Center (MIBC - Московский международный деловой центр, Moskovskiy mezhdunarodniy delovoy tsentr), also known as Moskva-City, (Москва-Сити, Moskva-Siti), is a commercial development located just east of the Third Ring Road (Тре́тье тра́нспортное кольцо́, Tretye Transportnoye Koltso), at the western edge of the Presnensky District (Пре́сненский райо́н) in the Central Administrative Okrug
} 
had already been relieved of his duties as mayor, when the Federation Tower was erected in the Moscow International Business Center. The architectural complex is composed of: Tower East ${ }^{1}$, Tower West and Spire. The Eastern tower is still the tallest buildings of the Russian capital, after the Ostankino TV Tower ${ }^{2}$. Before the Federation Tower four other complexes made of super-tall skyscrapers higher than 300 meter were built in the MIBC: the Mercury City Tower ${ }^{3}$, the OKO Towers ${ }^{4}$, the City of Capitals $^{5}$, and Eurasia ${ }^{6}$, which complete Moscow skyline together with three projects still under construction the Grand Tower ${ }^{7}$, the Neva Towers ${ }^{8}$, and the One Tower'.

Other MIBC buildings that are less than 300 meters high are: the Tower $2000^{10}$, the Empire ${ }^{11}$, the Evolution Tower ${ }^{1}$, the IQ-quarter ${ }^{2}$, the Naberezhnaya Tower ${ }^{3}$, and the Northern Tower ${ }^{4}$.

(Центра́льный администрати́вный о́круг, Tsentralny administrativny okrug), which is considered Moscow place for international business.

${ }^{1}$ With its 1227 feet, the super-tall skyscraper Восто́к (Vostok) is the tallest building in Europe and Russia after Lakhta Center (Лáхта це́нтр, Lakhta tsentr) in Saint Petersburg. The design is by GermanRussian engineer Sergei Tchoban (Сергей Энверович Чобан) and German professor and engineer Peter Schweger. The complex was designed by architecture companies nps+partner and Schweger Associated Architects. The construction started in 2005, with Запад (Zapad) completed first in 2008 with a height of 242 meters (794 feet). As a result of the Great Recession, construction of the complex stopped until August 2011, and Vostok was completed only at the end of 2017.

2 Ostankino Tower (Останкинская телебашня, Ostankinskaya telebashnya) is a television and radio tower designed by Nikolai Nikitin (Николай Васильевич Никитин) and built between 1963 and 1967. It is still the tallest free-standing structure in Europe and 11th tallest in the world.

${ }^{3}$ Меркурий Сити Тауэр (Merkuriy Siti Tauer) was developed by the American architect Frank Williams and the Russian engineering team Mosproject-2 (Моспроект-2), under the leadership of architect Mikhail Posokhin (Михаил Посохин).

${ }^{4}$ Oko means in Russian eye, but it is also an abbreviation for Ob'yedinonnyye Kristallom Osnovaniya (Объединённые Кристаллом Основания), which means in turn Joined by Crystal Foundation. The construction of the two skyscrapers, North Tower and South Tower, started in 2011 and finished in 2015. The project was assigned to the firm Skidmore, Owings and Merrill.

${ }^{5}$ For a detailed description please refer to Footnote 19.

${ }^{6}$ Евразия (Yevraziya), also known as Steel Peak (Стальная Вершина, Stalnaya Vershina) was built by Swanke Hayden Connell Architects between 2007 and 2014.

7 Conceived by Werner Sobek \& Ass., Башня «Гранд Тауэр» is a high-rise office tower to be constructed on top of an already existing basement structure. The twin towers will be coupled only by light bridges and the complex is supposed to be finished in 2020.

${ }^{8}$ Невские башни (Nevskiye Bashni), formerly named Renaissance Moscow Towers (Ренессанс Москва Башни, Renessans Moskva Bashni), is a complex of two skyscrapers. After Foster's original project had been abandoned, the ownership was partly transferred in 2014 to Rönesans Holding. The Turkish company hired ST Towers LLC to develop a new complex. SPEECH Architectural Bureau is also taking part in the project, in partnership with U.S. companies HOK and FXCollaborative and with public spaces designed by Hirsch Bedner Associates. The complex will be ready in 2020.

${ }^{9} 1$ Tower or Уан-тауэр. Its height upon completion in 2024 will be 405 meters with 101 floors, designed by the Sergey Skuratov Architects team. With this height it will be the tallest building in Moscow, second tallest building in Europe and Russia after Lakhta Center in Saint-Petersburg.

${ }^{10}$ Башня 2000 (Bashnya 2000), or Tower 2000. Built between 1996 and 2001 and designed by Boris Thor (Борис Тхор)

${ }^{11}$ Империя (Imperiya), formerly the Imperia Tower. Built between 2003 and 2018, it is a mixed-use complex which includes a completed 60-story skyscraper with a height of 239 metres (784 ft). The tower 
Due to the financial crisis of 2007-2008, the realization of the Russia Tower was cancelled. The original idea was already proposed in 1994 and the first model to win was the one by famous British architect Norman Foster, with a height of $1 \mathrm{~km}(0.62 \mathrm{mi})$, but Luzhkov did not give permission to start working. Foster presented a second project which consisted of a height reduced to $648 \mathrm{~m}$ and won again with a concept that included sky gardens as well as a park, shopping centre, aqua-park, power plant, mini-metro, linkage to the city underground system and a high-speed train to the international airport. Unfortunately, for this mega-project of «a city within a city» (Golubchikov, 2004, p. 240), which at that time might have been the world's tallest glass-sheathed skyscraper, was never built. The investment would have exceeded $\$ 10$ billion and, although the Moscow Government attached tax breaks to the site and various ownership incentives, but private investors were reluctant to put the money into such ambitious construction project, so it was not possible to finish the building with only public funds at disposal. Luzhkov considered the tall building as a unique «ornament» for Moscow City, as he declared during the inauguration ceremony of Russia Tower building site: ««We will not stop on building of this complex. Per se, we build a new city where streets grow upwards. Here we will have all facilities necessary for a person to live, work and enjoy his spare time. So the City won't be the final point in our plans. As you know, Moscow authorities is planning the possiblility of developing the industrial zone in Krasnaya Presnya region, so-called "Big City”» («Russia» on a start, 2007, p. 124). This speech makes us understand how a failure of the project was already expected. Moreover, the high-investment skyscraper construction was not favourably regarded by the Muscovites. With the economic crisis that was advancing, citizens considered the expensive project an emblem of the Moscow plutocracy.

The names of most of the above-mentioned tall buildings alternate the words bashnya and tower, forming a real linguistic pastiche. If we take into account the etymology of the two words, as explained before, they symbolized the Western and the Eastern lifestyle, alternately and in

belongs to the Russian businessman Oleg Malis (Оле́г Адо́льфович Ма́лис) and its concept is by Enka Design, in collaboration with NBBJ.

${ }^{1}$ Башия «Эволючия» (Bashnya Evolyutsiya). Built between 2011 and 2014, the 55-story office building has a height of 246 metres $(807 \mathrm{ft}$ ). Its futuristic DNA-like shape doesn't go unnoticed in. the building was designed by British architect Tony Kettle in collaboration with University of Edinburgh's Professor of Art Karen Forbes. Since 2016 it has been the headquarters of Transneft (Транснефть), the largest oil pipeline company in the world.

${ }_{2}^{2}$ IQ-квартал (IQ-kvartal). Built between 2008 and 2016, the mixed-use complex is composed of two skyscrapers and a high-rise building and was designed by NBBJ.

${ }^{3}$ Башня на Набережной (Bashnya na Naberezhnoy) literally means Tower on the Embankment. Built between 2003 and 2007, the office complex was designed by RTKL, in collaboration with Enka.

${ }^{4}$ Се́верная Ба́шня (Severnaya bashnya) was built between 2004 and 2007 by Strabag SE. 
combination. However, these buildings were also the tangible example of the absence of law in Moscow.

Moreover, in his last years as mayor, Luzhkov has lacked a comprehensive view of Moscow's urban development, especially if one considers the social gap between modern neighbourhoods with skyscrapers, that are part of Moscow's ambitious project as a global city, and the anonymous high-rise building of suburban ми́крорайоны ${ }^{l}$. Moreover, the above-mentioned severe international financial crisis slowed down the inflow of capital from abroad. Finally, corruption inside Luzhkov's clan in the management of Moscow public affairs became too evident and, therefore, badly tolerated not only by the citizens, but by the Putin-led federal elite. Luzhkov died recently, on December 10 of this year. At his funeral ceremony, Russian President Vladimir Putin said the following words in public: «He was a personality of truly extraordinary scale. A fiery, daring politician, an energetic and talented organiser and an open, kindhearted person» (Foy, 2019). Despite these fine words, Luzhkov was fired by Putin over loss of confidence in 2010. After returning from a holiday in Austria, the «Moscow Duce» was accused of massive fraud and dismissed by President Dmitry Medvedev at the end of September 2010.

Luzhkov was replaced with Sergey Sobyanin ${ }^{2}$, one of the loyal Governor-Siloviki. At the beginning of his term, Sobyanin continued "where Luzhkov left off, to the extent that he created the conditions to further commodify urban space and polarise society» (Büdenbender \& Zupan, 2017, p. 304). Luzhkov was dismissed because of a combination of global and local processes: the international financial crisis, the rise of a protest movement in Moscow and the intensification of rivalry between the federal and Moscow elites.

Sobyanin applied a new model for Moscow urban development, based on three key elements: the reorganisation of spatial boundaries and hierarchies; the upgrading of public spaces; and the adoption of critical urbanist initiatives and planning practices. A new city plan was announced already in 2011.

With the implementation of new city plans announced in 2011, Moscow has undergone a facelift. Sparkling glass façades have been juxtaposed with old, crumbling, unrenovated Soviet tower blocks. Orthodox churches destroyed years ago under Stalin have been entirely reconstructed, but with the addition of contemporary features for the twenty-first century. A new shopping arcade showcasing

\footnotetext{
${ }^{1}$ Microrayons or microdistricts.

${ }^{2}$ Серге́й Семёнович Собя́нин.
} 
Western fashions at eye-watering prices has been implanted in the city centre, topped with a cupola and mythological figures. A giant park has been unveiled to glorify Soviet triumphs in war, including as its centrepiece the figure of St George slaying the dragon. The Stalinist vysotki, the seven elaborate skyscrapers scattered across the city's Soviet landscape, have welcomed twenty-first-century additions to their ranks. A collection of giant skyscrapers has also arisen from the banks of the river to form a new business district, which includes the tallest building in Europe (Griffiths, 2014, p. 53).

In the first months of his term of office, Sobyanin tried to lift Moscow out of the economic crisis and create new urban spaces, through a new regulation of the urban economy and a better quality of urban space. Following canons in contrast to the past, Sobyanin tried to abandon a populist and authoritarian approach towards Muscovites, that had characterized the Luzhkov era. He replaced the old managers of the city planning department with young officials who attended universities in Europe and the United States, showing citizens an administration that, at least apparently, seemed more transparent than the previous one. In this context, developing high-rise construction was economically advantageous in a megacity like Moscow, which aimed to be a centre of international trade. At the same time, supertall skyscrapers gave prestige to the administration, having an effect of economic stability and international prestige (Sergievskaya, Pokrovskaya, \& Vorontsova, 2018). After the financial crisis, Moscow has returned at the beginning of the second decade of the new millennium to a city with a strong global potential, being part of the mosaic of international urban planning models through building best practices, that reflected the tastes of the Western-oriented middle class. A new urban strategy was adopted, which promoted Moscow as a comfortable city $^{1}$, in sharp contrast with the neoliberal urbanism of Luzhkov era.

Sobyanin has also encouraged competitions open to foreign architectural firms and public events with international relevance dedicated to urban planning, such as the Moscow Architectural Biennale, the Moscow Urban Forum, and the SSC Conference. Sobyanin's «New Moscow» ${ }^{2}$ has

\footnotetext{
${ }^{1}$ «When Sergey Sobyanin was appointed in 2010, his administration developed a five-year programme called "Moscow: a city comfortable for life" (Pravitelstvo Moskvy 2014). This programme began in 2013 and entailed a shift in the city's placemaking strategy, rebranding Moscow's profile into a convenient city with a high-quality urban environment» (Büdenbender \& Zupan, 2017, p. 303).

2 «Following the proposals for the construction of New Moscow in the summer of 2011, the old city's boundaries were drastically extended on 1 July 2012, thereby increasing its territory by 2.39 times. By focusing on Luzhkov's manipulation of the past in space, the strengthening of concentric Moscow, the
} 
been transformed from a chaotic to a comfortable city, from an authoritarian citadel to a space belonging to the people. But in the last two years the current mayor of Moscow has aimed at transforming the New City into the Business City, despite economic sanctions and difficult relations with the West. The new organization of Moscow's urban space has replaced the concentric structure that has characterized the city for over eighty years with a rather eccentric image of the peripheries. In 2017 Sobyanin decided to get rid of the anonymous image of the Moscow suburbs inherited from the Soviet period through a controversial demolition program of more than 4,000 housing estates built between the 1950s and 1960s in various location across the city (Andreev, 2018) ${ }^{1}$.

From a conglomerate of monotonous apartment complexes inherited from the Soviet era to upscale downtown condominiums and spectacular compounds at the edge of the city and beyond, including the development of a new "Business City" three miles away from the Red Square (Medvedkov \& Medvedkov, 2007, p. 245).

Between May and June 2017 thousands of Muscovites took to the streets to protest against mass demolitions. Sobyanin's plan was subjected to vigorous criticism because of the threat to infringe of right of private property (Evans, 2018). On May the $14 \mathrm{t}^{\mathrm{h}}$ protesters gathered around the metro station Chistyye Prudy ${ }^{2}$ (Чи́стые пруды́), on May the $27^{\text {th }}$ May, Suvorovskaya square ${ }^{3}$, and on June the $12^{\text {th }}$ on the Sakharov Boulevard ${ }^{4}$. He declared at the 2018 Moscow Urban Forum that: «The development of Moscow is not a threat, but the locomotive of development of the whole country». Sobyanin has dusted off the term «blagoustroistvo» from the past, giving it a mundane meaning 5 , but the critical attitude of citizens towards urban planning policies is an indication that the Russian rigid authoritarian system has cracks that are slowly expanding. Sobyanin's attempt to reconcile an autocratic management of the city based on the parameters and instruments typical of Western democracies with the

aspirations to render Moscow a global player, and the latest plans to build New Moscow» (Griffiths, 2014, p. 54).

${ }^{1}$ Seе Правительство Москвы, Постановление, О Программе реновации жилищного фонда в городе Москве, (last accessed 26 December 2019). The Khrushchyovki peak, as it is called in the decree «Programme of Renovation of the housing stock» of August the $1^{\text {st }}$ 2017, was reached in 1963-1964, when 2.5 million $\mathrm{km} 2$ of housing were built (Decree N-497 2017).

${ }^{2}$ Чи́стые пруды́.

${ }^{3}$ Суворовская площадь.

${ }^{4}$ Проспект Академика Сахарова (Prospekt Akademika Sakharova).

${ }^{5}$ Благоустройство is an untranslatable Russian word referring to the improvement (and/or beautification) of public services or infrastructure (Воскресенская, 2008). Blagoustroistvo means something like the arrangement, provision or construction (устройство, ustroistvo) of a blessing (благо, blago). 
Журнал Фронтирных Исследований. 2020. No 1 | e-ISSN: 2500-0225

Границы идентичности и пространственные границы города | doi: 10.24411/2500-0225-2020-10004

transparency of political processes and the consent of the people presents risks of social tensions and unrest.

\section{CONCLUSION}

Today Moscow is pervaded by a ferment which is typical of the new financial capitals. Its contemporary urban grandeur is based on high-rise buildings inserted in the pre-existing circular, hierarchical-feudal structure, designed for the Seven Sisters around the Kremlin, which is considered the heart of the city. Today Moscow is a multi-ethnic megalopolis and the habitat of the post-sovky (post-Homo Sovieticus), with its new dizzying skyscrapers, symbols of a social and urban change, that once again consecrates Moscow to an extraordinary urban laboratory. With the transition from State to private ownership and the abolition of propiskas, residential mobility has increased significantly, bringing with it a greater awareness of urban sustainability among citizens. Therefore, the Muscovites strongly demand today buildings that are suitable for the needs of a free market economy, but also liveable places. De facto, however, innovative building construction is concentrated in the Business City, which is integrated into global capital flows. Its skyline is made up of avant-garde offices and luxury hotels, built like a panacea that seems to remain only an ideological construction that is struggling to materialize. And while Moscow tries to develop in a polycentric way, paradoxically the Russian Federation is trapped by centipede forces. Despite its attempt to find its own identity independent of the central government, Moscow exudes power through its modern turreted belt, confusingly superimposing different images, starting from the Nineteenth-century matushka-Moskva to the eclectic pastiche of the Moscow City, made of huge glass towers. This phenomenon confirms once again that an ideological symbolism remains imprinted on Moscow urban landscape. The image of the heroic statues of the past, obscured by the new skyscrapers, confirm a constant utopian dispersion, that overshadows Moscow urban development of the 21st century.

\section{References}

Alden, J., Beigulenko, Y., \& Crow, S. (1998). Moscow: Planning for a world capital city towards 2000. Cities, 15(5), 361-374.

Andreev, I. (2018). Moscow program of renovation of housing in the context of inter-party competition. MATEC Web of Conferences, 251, 1-11. DOI: 10.1051/matecconf/201825105038 
Andrusz, G. D. (1984). Housing and Urban Development in the USSR. Albany, N.Y.: State University of New York Press.

Argenbright, R. (2018). The evolution of New Moscow: from panacea to polycentricity. Eurasian Geography and Economics, 59(3-4), 408435.

Astapova, A. (2013). To what Extent are Jokes Reactional? (Based on a Joke Cycle about Yury Luzhkov's Dismissal). Folklore: Electronic Journal of Folklore, 53, 7-28.

Barthes, R. (1986). Semiology and the Urban. The city and the sign: An introduction to urban semiotics, 8, 7-98.

Barthes, R. (1988). Semiology and urbanism. In R. Barthes. The semiotic challenge (pp. 191-201). New York: Hill a. Wang.

Behrends, J. C. (2015). Constructing a New Moscow: Observations on a Changing Symbol of Soviet Modernity. New Literary, 133(3), 18-29. (in Russian)

Blake, P. (1947). The Soviet Architecture Purge. Architectural Record, 106(3), 127-129.

Retrieved from https://www.architecturalrecord.com/articles/11452-the-sovietarchitecture-purge

Brandenberger, D. (2002). National Bolshevism: Stalinist mass culture and the formation of modern Russian national identity, 1931-1956 (Russian Research Center studies, Vol. 93). Cambridge, MA: Harvard University Press.

Büdenbender, M., \& Zupan, D. (2017). The evolution of neoliberal urbanism in Moscow, 1992-2015. Antipode, 49(2), 294-313.

Cetin, M. (2011). Moscow; an urban pendulum swinging between the glorification of the proletariat and the celebration of absolutist power under the changing winds of globalization. International Journal of Civil \& Environmental Engineering, 11(3), 1-12.

Clark, T., \& Tsibizova, L. (2017). The architectural legacy of 1990s Moscow: [Interview with Daria Paramonova]. In Russia, History. Retrieved from http://inrussia.com/the-architectural-legacy-of-1990smoscow.

Cooke, C. (1997). Beauty as a route to 'the Radiant Future': Responses of Soviet architecture. Journal of Design History, 10(2), 137-160.

Demintseva, E. (2017). Labour migrants in post-Soviet Moscow: patterns of settlement. Journal of ethnic and migration studies, 43(15), 25562572.

Djilas, M. (1957). The New Class: An Analysis of the Communist System. Montreal: Harvest House. 
Dmitrieva, M. (2006). Moscow architecture between Stalinism and Modernism. International Review of Sociology-Revue Internationale de Sociologie, 16(2), 427-450.

Evans, A. (2018). Property and Protests: The Struggle Over the Renovation of Housing in Moscow. Russian Politics, 3(4), 548-576. DOI: 10.1163/2451-8921-00304005

Foy, H. (2019, December) Yuri Luzhkov, Russian politician, 1936-2019: The mayor who rebuilt Moscow in his own image. Financial Times. Retrieved from https://www.ft.com/content/b886a468-1c29-11ea9186-7348c2f183af.

Golovina, S., \& Oblasov, Y. (2018). The architecture and artistic features of high-rise buildings in USSR and the United States of America during the first half of the twentieth century. In E3S Web of Conferences, (Vol. 33, pp. 1-18). DOI: $10.1051 / \mathrm{e} 3$ sconf $/ 20183301032$

Golubchikov, O. (2004). Urban planning in Russia: towards the market. European Planning Studies, 12(2), 229-247.

Griffiths, M. J. (2014). Writing the cityscape: Narratives of Moscow since 1991 (Doctoral dissertation, UCL. University College London).

Gunko, M., Bogacheva, P., Medvedev, A., \& Kashnitsky, I. (2018). PathDependent Development of Mass Housing in Moscow, Russia. In D. B. Hess, T. Tammaru, \& M. van Ham, (Eds.). Housing Estates in Europe (pp. 289-311). Cham: Springer International Publishing.

Harding, L. (2013). Homo Sovieticus: Stalin's failed European experiment. New Eastern Europe, 6(1), 145-147.

Harvey, D. (2003). The right to the city. International Journal of Urban and Regional Research, 27(4), 939-941.

Hoisington, S. S. (2003). "Ever higher": the evolution of the project for the Palace of Soviets. Slavic Review, 62(1), 41-68.

Honda, A. (2012). Post-Soviet Architecture: Future-phobia. Japanese Slavic and East European Studies, 33, 3-16.

Humphrey, C. (2002). The unmaking of Soviet life: Everyday economies after socialism. Ithaca, N.Y.; London: Cornell University Press.

Huxtable, A. L. (1984). The Tall Building Artistically Reconsidered: The Search for a Skyscraper Style. New York: Pantheon Books.

Iconopisceva, O. G., \& Proskurin, G. A. (2018). Regional approaches in high-rise construction. In E3S Web of Conferences, (Vol. 33, pp.110). DOI: $10.1051 / \mathrm{e} 3$ sconf/ 20183301023

Inizan, G., \& de Lille, L. C. (2019). The last of the Soviets' home: Urban demolition in Moscow. Geographia Polonica, 92(1), 37-56. 
Jensen, D. N. (2000). The boss: How Yury Luzhkov runs Moscow. Demokratizatsiya, 8(1), 83-122.

Kappeler, A. (2008). Rußland als Vielvölkerreich: Entstehung-GeschichteZerfall (Beck'sche Reihe, Vol. 1447). München: CH Beck.

Kopp, A. (1985). Le gigantisme architectural en Union soviétique. Communications, 42(1), 45-67.

Kosareva, N., \& Struyk, R. (1993). Housing privatization in the Russian Federation. Housing Policy Debate, 4(1), 81-100.

Kruzhkov, N. (2014). High-rise Stalinist Moscow. Legacy of the era. Moscow: Centrepoligraph Publishing House. (in Russian)

Kuznetsov, S. (2015b) Sergey Kuznetsov: We needed to find a sensible compromise between user comfort and price. In Project Russia (77, New standards (3), pp. 64-71). Moscow, Amsterdam: A-Fond Publishers.

Le Corbusier (1991). Precisions on the present state of architecture and city planning: With an American prologue, a Brazilian corollary followed by the temperature of Paris and the atmosphere of Moscow (E. S. Aujame, trans.). Cambridge, MA; London: Mit Press.

Lefebvre, H. (1996). The right to the city. In H. Lefebr. Writings on cities (pp. 63-181). Oxford: Blackwell.

Lemon, A. (2000). Talking transit and spectating transition: The Moscow metro. In D. Berdahl, M. D. Bunzl, \& M. Lampland, M. (Eds.). Altering States: ethnographies of transition in Eastern Europe and the former Soviet Union (pp. 14-39). Ann Arbor, Mich.: University of Michigan Press.

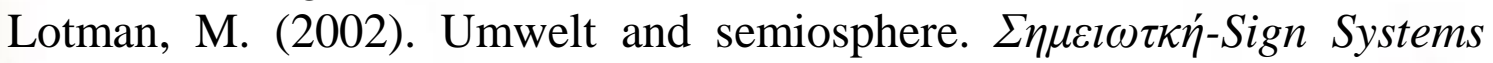
Studies, 30(1), 33-40.

Maslovskaya, O., \& Ignatov, G. (2018). Conceptions of Height and Verticality in the History of Skyscrapers and Skylines. In E3S Web of Conferences, (Vol. 33(1)3, pp. 1-7). DOI: $10.1051 / \mathrm{e} 3$ sconf/20183301005

Medvedkov, Y., \& Medvedkov, O. (2007). Upscale housing in post-Soviet Moscow and its environs. In K. Stanilov, (Ed.). The post-socialist city (pp. 245-265). Dordrecht: Springer.

Montefiore, S. S. (2004). Stalin: The court of the red tsar. London: Phoenix.

Paperny, V. (2006). Culture two (2nd ed.). Moscow: New Literary Observer. (in Russian)

Paramonova, D. (2013). Mushrooms, Mutants and Others: Architecture of the Luzhkov Era. Moscow: Strelka press. (in Russian) 
Pliukhanova, M. B. (1995). Plots and symbols of the Moscow Kingdom (Vol. 2). S.-Petersburg: Akropol. (in Russian)

«Russia» on a start, (2007). Tall Buildings, 5, 124.

Sergievskaya, N., Pokrovskaya, T. \& Vorontsova, N. (2018). The advisability of high-rise construction in the city. E3S Web of Conferences, 33, 01-10. DOI: 10.1051/e3sconf/20183301037

Simmel, G. (1997). The Sociology of Space. In D. Frisby \& M. Featherstone (Eds.), Simmel on culture: Selected writings (pp. 137169). London: Sage.

Simon, E., Simon, S., Robson, W. A., \& Jewkes, J. (2014). Moscow in the Making. London, New York: Routledge.

Smith, M. B. (2010) Property of communists: The urban housing program from Stalin to Khrushchev. DeKalb, Ill.: Northern Illinois University Press.

Soja, E. W. (2003). Writing the city spatially. City, 7(3), 269-280.

Starodubtsev, Y., Myers, J., \& Goetz, L. (2011). Case study: Capital city towers, Moscow. CTBUH Journal, (2), 12-17.

Starr, S. F. (1979). The social character of Stalinist architecture. Architectural Association Quarterly, 11(2), 49-55.

Van Baak, J. (2009). Anti-Houses. Under the doom of the kommunalka. Deformations of the utopian house. In J. J. Van Baak, R. Grübel, A. G. F. Van Holk, \& W. G., Weststeijn., The house in Russian literature: A mythopoetic exploration (Studies in Slavic Literature and Poetics, vol. 53, pp. 419-426). Amsterdam, New York: Rodopi.

Vasilyeva, A. V. \& Kosenkova, Y. L. (2015). Social tasks and practice of housing development of Moscow during 1930-1940 years. In The New Ideas of New Century. The International Scientific Conference Proceedings of the FAD PNU (Vol.1, pp. 37-43). Khabarovsk: Published by PNU. (in Russian)

Vendina, O. I. (2004). Are Ethnic Neighborhoods Possible in Moscow? The Russian Public Opinion Herald. Data. Analysis. Discussions, 3, 52-64. (in Russian)

Wolfe, R. L. (2013). Stalinism in art and architecture, or, the first postmodern style. Situations: Project of the Radical Imagination, $5(1)$.

Zeltsman, I. (2011). Luzhkov and Void. Grigory Revzin's conversation with students of the Strelka Institute. In Project Russia (62(4), pp. 81-91). Moscow, Amsterdam: A-Fond Publishers. (in Russian)

Zlydneva, N. (2008). The tower as a semiotic message. In E. Näripea, V. Sarapik, J. Tomberg (Eds.) Koht ja Paik = Place and Location (VI, pp. 83-90). Tallinn: Eesti Kirjandusmuuseum. 
Zupan, D., \& Büdenbender, M. (2018). Neoliberale Stadtentwicklung in Transformation. Pnd Online: ein Magazin mit texten und Diskussionen zur Entwicklung von Stadt und Region, 1, 103-112.

\section{Список литературы}

«Russia» on a start, (2007). Tall Buildings, 5, 124.

Alden, J., Beigulenko, Y., \& Crow, S. (1998). Moscow: Planning for a world capital city towards 2000. Cities, 15(5), 361-374.

Andreev, I. (2018). Moscow program of renovation of housing in the context of inter-party competition. MATEC Web of Conferences, 251, 1-11. DOI: $10.1051 /$ matecconf/201825105038

Andrusz, G. D. (1984). Housing and Urban Development in the USSR. Albany, N.Y.: State University of New York Press.

Argenbright, R. (2018). The evolution of New Moscow: from panacea to polycentricity. Eurasian Geography and Economics, 59(3-4), 408435.

Astapova, A. (2013). To what Extent are Jokes Reactional? (Based on a Joke Cycle about Yury Luzhkov's Dismissal). Folklore: Electronic Journal of Folklore, 53, 7-28.

Barthes, R. (1986). Semiology and the Urban. The city and the sign: An introduction to urban semiotics, 8, 7-98.

Barthes, R. (1988). Semiology and urbanism. In R. Barthes. The semiotic challenge (pp. 191-201). New York: Hill a. Wang.

Blake, P. (1947). The Soviet Architecture Purge. Architectural Record, 106(3), 127-129.

Retrieved from

https://www.architecturalrecord.com/articles/11452-the-sovietarchitecture-purge

Brandenberger, D. (2002). National Bolshevism: Stalinist mass culture and the formation of modern Russian national identity, 1931-1956 (Russian Research Center studies, Vol. 93). Cambridge, MA: Harvard University Press.

Büdenbender, M., \& Zupan, D. (2017). The evolution of neoliberal urbanism in Moscow, 1992-2015. Antipode, 49(2), 294-313.

Cetin, M. (2011). Moscow; an urban pendulum swinging between the glorification of the proletariat and the celebration of absolutist power under the changing winds of globalization. International Journal of Civil \& Environmental Engineering, 11(3), 1-12.

Clark, T., \& Tsibizova, L. (2017). The architectural legacy of 1990s Moscow: [Interview with Daria Paramonova]. In Russia, History. 
Retrieved from http://inrussia.com/the-architectural-legacy-of-1990smoscow.

Cooke, C. (1997). Beauty as a route to 'the Radiant Future': Responses of Soviet architecture. Journal of Design History, 10(2), 137-160.

Demintseva, E. (2017). Labour migrants in post-Soviet Moscow: patterns of settlement. Journal of ethnic and migration studies, 43(15), 25562572.

Djilas, M. (1957). The New Class: An Analysis of the Communist System. Montreal: Harvest House.

Dmitrieva, M. (2006). Moscow architecture between Stalinism and Modernism. International Review of Sociology-Revue Internationale de Sociologie, 16(2), 427-450.

Evans, A. (2018). Property and Protests: The Struggle Over the Renovation of Housing in Moscow. Russian Politics, 3(4), 548-576. DOI: 10.1163/2451-8921-00304005

Foy, H. (2019, December) Yuri Luzhkov, Russian politician, 1936-2019: The mayor who rebuilt Moscow in his own image. Financial Times. Retrieved from https://www.ft.com/content/b886a468-1c29-11ea9186-7348c2f183af.

Golovina, S., \& Oblasov, Y. (2018). The architecture and artistic features of high-rise buildings in USSR and the United States of America during the first half of the twentieth century. In E3S Web of Conferences, (Vol. 33, pp. 1-18). DOI: $10.1051 / \mathrm{e} 3$ sconf $/ 20183301032$

Golubchikov, O. (2004). Urban planning in Russia: towards the market. European Planning Studies, 12(2), 229-247.

Griffiths, M. J. (2014). Writing the cityscape: Narratives of Moscow since 1991 (Doctoral dissertation, UCL. University College London).

Gunko, M., Bogacheva, P., Medvedev, A., \& Kashnitsky, I. (2018). PathDependent Development of Mass Housing in Moscow, Russia. In D. B. Hess, T. Tammaru, \& M. van Ham, (Eds.). Housing Estates in Europe (pp. 289-311). Cham: Springer International Publishing.

Harding, L. (2013). Homo Sovieticus: Stalin's failed European experiment. New Eastern Europe, 6(1), 145-147.

Harvey, D. (2003). The right to the city. International Journal of Urban and Regional Research, 27(4), 939-941.

Hoisington, S. S. (2003). "Ever higher": the evolution of the project for the Palace of Soviets. Slavic Review, 62(1), 41-68.

Honda, A. (2012). Post-Soviet Architecture: Future-phobia. Japanese Slavic and East European Studies, 33, 3-16. 
Humphrey, C. (2002). The unmaking of Soviet life: Everyday economies after socialism. Ithaca, N.Y.; London: Cornell University Press.

Huxtable, A. L. (1984). The Tall Building Artistically Reconsidered: The Search for a Skyscraper Style. New York: Pantheon Books.

Iconopisceva, O. G., \& Proskurin, G. A. (2018). Regional approaches in high-rise construction. In E3S Web of Conferences, (Vol. 33, pp.110). DOI: $10.1051 / \mathrm{e} 3$ sconf/ 20183301023

Inizan, G., \& de Lille, L. C. (2019). The last of the Soviets' home: Urban demolition in Moscow. Geographia Polonica, 92(1), 37-56.

Jensen, D. N. (2000). The boss: How Yury Luzhkov runs Moscow. Demokratizatsiya, 8(1), 83-122.

Kappeler, A. (2008). Rußland als Vielvölkerreich: Entstehung-GeschichteZerfall (Beck'sche Reihe, Vol. 1447). München: CH Beck.

Kopp, A. (1985). Le gigantisme architectural en Union soviétique. Communications, 42(1), 45-67.

Kosareva, N., \& Struyk, R. (1993). Housing privatization in the Russian Federation. Housing Policy Debate, 4(1), 81-100.

Kuznetsov, S. (2015b) Sergey Kuznetsov: We needed to find a sensible compromise between user comfort and price. In Project Russia (77, New standards (3), pp. 64-71). Moscow, Amsterdam: A-Fond Publishers.

Le Corbusier (1991). Precisions on the present state of architecture and city planning: With an American prologue, a Brazilian corollary followed by the temperature of Paris and the atmosphere of Moscow (E. S. Aujame, trans.). Cambridge, MA; London: Mit Press.

Lefebvre, H. (1996). The right to the city. In H. Lefebr. Writings on cities (pp. 63-181). Oxford: Blackwell.

Lemon, A. (2000). Talking transit and spectating transition: The Moscow metro. In D. Berdahl, M. D. Bunzl, \& M. Lampland, M. (Eds.). Altering States: ethnographies of transition in Eastern Europe and the former Soviet Union (pp. 14-39). Ann Arbor, Mich.: University of Michigan Press.

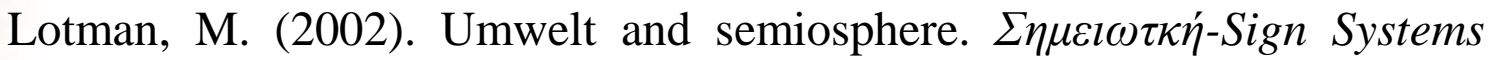
Studies, 30(1), 33-40.

Maslovskaya, O., \& Ignatov, G. (2018). Conceptions of Height and Verticality in the History of Skyscrapers and Skylines. In E3S Web of Conferences, (Vol. 33(1)3, pp. 1-7). DOI: $10.1051 / \mathrm{e} 3$ sconf/20183301005

Medvedkov, Y., \& Medvedkov, O. (2007). Upscale housing in post-Soviet Moscow and its environs. In K. Stanilov, (Ed.). The post-socialist city (pp. 245-265). Dordrecht: Springer. 
Montefiore, S. S. (2004). Stalin: The court of the red tsar. London: Phoenix.

Sergievskaya, N., Pokrovskaya, T. \& Vorontsova, N. (2018). The advisability of high-rise construction in the city. E3S Web of Conferences, 33, 01-10. DOI: 10.1051/e3sconf/20183301037

Simmel, G. (1997). The Sociology of Space. In D. Frisby \& M. Featherstone (Eds.), Simmel on culture: Selected writings (pp. 137169). London: Sage.

Simon, E., Simon, S., Robson, W. A., \& Jewkes, J. (2014). Moscow in the Making. London, New York: Routledge.

Smith, M. B. (2010) Property of communists: The urban housing program from Stalin to Khrushchev. DeKalb, Ill.: Northern Illinois University Press.

Soja, E. W. (2003). Writing the city spatially. City, 7(3), 269-280.

Starodubtsev, Y., Myers, J., \& Goetz, L. (2011). Case study: Capital city towers, Moscow. CTBUH Journal, (2), 12-17.

Starr, S. F. (1979). The social character of Stalinist architecture. Architectural Association Quarterly, 11(2), 49-55.

Van Baak, J. (2009). Anti-Houses. Under the doom of the kommunalka. Deformations of the utopian house. In J. J. Van Baak, R. Grübel, A. G. F. Van Holk, \& W. G., Weststeijn., The house in Russian literature: A mythopoetic exploration (Studies in Slavic Literature and Poetics, vol. 53, pp. 419-426). Amsterdam, New York: Rodopi.

Wolfe, R. L. (2013). Stalinism in art and architecture, or, the first postmodern style. Situations: Project of the Radical Imagination, $5(1)$.

Zlydneva, N. (2008). The tower as a semiotic message. In E. Näripea, V. Sarapik, J. Tomberg (Eds.) Koht ja Paik = Place and Location (VI, pp. 83-90). Tallinn: Eesti Kirjandusmuuseum.

Zupan, D., \& Büdenbender, M. (2018). Neoliberale Stadtentwicklung in Transformation. Pnd Online: ein Magazin mit texten und Diskussionen zur Entwicklung von Stadt und Region, 1, 103-112.

Берендс, Я. К. (2015). Строительство новой Москвы: меняющийся символ советской модерности. Новое литературное обозрение, 133(3), 18-29.

Васильева, А. В. \& Косенкова, Ю. Л. (2015). Социальные задачи и практика жилищного строительства Москвы рубежа 1930-1940х годов. В Новые идеи нового века: Материаль международной научной конференции ФАД ТОГУ (Т.1, сс. 37-43). Хабаровск: ФГБОУ ВО «Тихоокеанский государственный университет». 
Вендина, О. И. (2004). Могут ли в Москве возникнуть этнические кварталы? Вестник общественного мнения, 3, 52-64.

Зельцман, И. (2011). Лужков и пустота. Беседа Григория Ревзина со студентами Института Стрелка. In Проект Россия = Project Russia (62(4), сс. 81-90). Москва: А-Фонд; Амстердам: A-Fond Publishers.

Кружков, Н. (2014). Высотки сталинской Москвы. Наследие эпохи. Москва: Центрполиграф.

Паперный, В. (2006). Культура два (2-е изд., испр. и доп.). Москва: Новое литературное обозрение.

Парамонова, Д. (2013). Грибы, мутанты и другие: архитектура эры Лужкова. Москва: Стрелка Пресс.

Плюханова, М. Б. (1995). Сюжеты и символь Московского ияарства (Т. 2). С.-Петербург: Акрополь. 